DOI: 10.20472/IAC.2017.029.024

\title{
SULEIMAN MOHAMMAD
}

Al al-Bayt University, Jordan

\author{
THENAYYAN HUSAIN \\ KUWAIT OILCOMPANY, Kuwait
}

\section{THE IMPACT OF ELECTRONIC HUMAN RESOURCES MANAGEMENT PRACTICES ON ORGANIZATIONAL LEARNING CAPABILITIES OF THE COMMERCIAL BANKS WORKING IN JORDAN}

\begin{abstract}
:
The study aimed to examine the impact of electronic human resource management practices on Organizational learning capabilities in commercial banks working in Jordan. The electronic human resource management practices represented by (recruitment and selection, training and development, performance appraisal, compensation, and communication). Regarding the organizational learning capabilities which represented by (Experimentation, Risk Taking, Interaction with the external environment, dialogue, participative decision making). The population of the study consisted of workers at commercial banks working in Jordan, a random sample was taken amounted (400) participants, SPSS was used to examine the study hypotheses and achieve its objectives.

The researcher found that there is statistical significant impact of the electronic Human Resources management practices (recruitment and selection, Training and development, performance appraisal, compensation, and communication) on organizational learning capabilities in commercial banks working in Jordan. The researcher recommended the adoption of electronic human resource management practices and these practices on the ground in all sectors of Jordan, which will have positive results regarding the organizational learning capabilities
\end{abstract}

\section{Keywords:}

Electronic human resource management, Organizational learning capabilities, commercial banks, Jordan

JEL Classification: M00 